\title{
Analisis Hukum Islam Terhadap Khiyar Dalam Jual Beli Sembako Di Pasar Wage Kabupaten Nganjuk
}

\author{
Ahmad Syaickhu ${ }^{1}$, Alfin Yuli Dianto ${ }^{2}$, Sulvi Dewi Pertiwi ${ }^{3}$ \\ ${ }^{1}$ Institut Agama Islam Pangeran Diponegoro Nganjuk. Jl.Wilis Kramat,Nganjuk. \\ ${ }^{2}$ Institut Agama Islam Pangeran Diponegoro Nganjuk. Jl.Wilis Kramat,Nganjuk. \\ 3Institut Agama Islam Pangeran Diponegoro Nganjuk. Jl.Wilis Kramat,Nganjuk. \\ E-mail: syaickhahmad@gmail.com
}

\begin{abstract}
:
Islamic law is a law that originates and becomes a part of Islam, when talking about laws that come to mind are the rules or norms that regulate human behavior in a society. The form may be unwritten laws or customary laws and laws that are deliberately made by humans to regulate human relationships with one another. In fulfilling the necessities of life, humans meet and complement each other as social beings. In this study, the problem raised is how the form and process of applying khiyar in the sale and purchase of groceries is reviewed in Islamic law. The purpose of this research is to find out how the form and process of applying khiyar in the sale and purchase of groceries at Pasar Wage, Nganjuk Regency. The research method used is a qualitative research approach. Primary data sources are traders and buyers at Wage Nganjuk Market, while secondary data sources are archives and documentation. Sample of ten traders and buyers. data collection techniques in the form of observation, interviews, and documentation. Meanwhile, the data analysis technique makes direct observations by relying on the researcher's imagination, enthusiasm and creativity. The results of the research The application of the buying and selling transaction process in Pasar Wage, Nganjuk Regency has been high and the majority has been implemented.
\end{abstract}

Keywords: Islamic Law, Khiyar, Staple Food

\begin{abstract}
:
Hukum Islam merupakan hukum yang bersumber dan menjadi bagian dalam agama Islam, ketika berbicara tentang hukum yang terlintas dalam pikiran adalah peraturan-peraturan atau norma-norma yang mengatur tingkah laku manusia dalam suatu masyarakat. Bentuknya mungkin hukum yang tidak tertulis atau hukum adat dan hukum yang sengaja dibuat oleh manusia untuk mengatur hubungan manusia satu dengan manusia yang lainnya. Dalam mencukupi kebutuhan hidupnya, manusia saling memenuhi dan saling melengkapi layaknya sebagai makhluk social. Dalam penelitian ini, masalah yang diangkat adalah Bagaimanakah bentuk dan proses penerapan khiyar dalam jual beli sembako ditinjau dalam hukum Islam. Tujuan dari diadakannya penelitian ini adalah untuk mengetahui bagaimana bentuk dan proses penerapan khiyar dalam transaksi jual beli sembako di Pasar Wage Kabupaten Nganjuk. Metode Penelitian yang digunakan adalah pendekatan penelitian kualitatif. Sumber data primer berupa pedagang dan pembeli di Pasar Wage Nganjuk sedangkan sumber data sekunder berupa arsip-arsip dan dokumentasi. Sampel sepuluh pedagang dan pembeli. teknik pengumpulan data berupa observasi, wawancara, dan dokumentasi. Sedangkan teknis analisis data melakukan pengamatan secara langsung dengan mengandalkan daya imajinasi, antusias, dan daya kreasi peneliti. Hasil penelitian Penerapan proses transaksi jual beli di Pasar Wage Kabupaten Nganjuk sudah tinggi dan mayoritas sudah diterapkan.
\end{abstract}

Keywords : Hukum Islam, Khiyar, Sembako 


\section{PENDAHULUAN}

Hukum Islam merupakan hukum yang bersumber dan menjadi bagian dalam agama Islam, ketika berbicara tentang hukum yang terlintas dalam pikiran adalah peraturan-peraturan atau normanorma yang mengatur tingkah laku manusia dalam suatu masyarakat. Bentuknya mungkin hukum yang tidak tertulis atau hukum adat dan hukum yang sengaja dibuat oleh manusia untuk mengatur hubungan manusia satu dengan manusia yang lainnya. Dalam mencukupi kebutuhan hidupnya, manusia saling memenuhi dan saling melengkapi layaknya sebagai makhluk sosial. ${ }^{1}$

Hukum kehidupan bermuamalat, Islam telah memberikan garis kebijakan yang jelas. Muamalat sebagai tempat setiap orang melakukan perbuatan dalam hubungan dengan orang lain yang menimbulkan hak dan kewajiban itu merupakan bagian terbesar dalam hidup manusia. Oleh karenanya, agama Islam menempatkan bidang muamalat ini sedemikian pentingnya. Salah satu bidang muamalat yang disyari' atkan oleh Allah SWT adalah jual beli. ${ }^{2}$

Mendengar jual beli tentulah tidak dapat dipisahkan dari pasar dan berdagang adalah aktifitas yang paling umum dilakukan. Pasar merupakan alat yang memungkinkan individu berinteraksi untuk membeli barang atau jasa tertentu. Menurut kajian ilmu ekonomi, pasar adalah suatu tempat atau interaksi antara permintaan (pembeli) dan penawaran (penjualan) dari suatu barang atau jasa tertentu, sehingga akhirnya dapat menetapkan harga keseimbangan (harga pasar) dan jumlah yang diperdagangkan. Islam telah memberikan tuntunan dalam melaksanakan jual beli, agar tidak ada yang merasa dirugikan antara penjual dan pembeli. Tuntunan yang diberikan oleh Islam antara lain dengan adanya kerelaan dengan kedua belah pihak yang berakad, dan barang yang dijadikan objek dalam jual beli dapat dimanfaatkan menurut kriteria dan realitanya. Jual beli mendapatkan berkah dari Allah adalah jual beli yang jujur, yang tidak curang. Tidak mengandung unsur penipuan dan pengkhianat.

Di samping itu hukum Islam memberikan solusi sebagai pelengkap daripada rukun dan syarat jual beli yang terpenuhi, yakni berupa Khiyar. Hal ini bertujuan untuk melindungi dari kemungkinan penipuan dari pihak penjual. Jual beli dalam Islam selalu memperhatikan maslahat-maslahat yang Allah syariatkan berupa hak milik bagi orang yang bertransaksi supaya dia puas melihat maslahat dan mudharat yang ada dari sebab akad tersebut sehingga dia mendapatkan apa yang diharapkannya dari pilihannya itu atau membatalkan jual belinya (Sabiq, 1983:164). ${ }^{3}$

Bukan merupakan rahasia lagi dan sudah menjadi pendapat umum di kalangan pengusaha yang sukses untuk selalu mengikuti motto pembeli adalah raja. Konsep pemasaran maju (the old concept of marketing), yang akan dibahas dalam pembahasan berikut ini yakni orientasi pemasaran yang maju. Pasar dapat pula diartikan sebagai suatu kelompok orang-orang yang diorganisasikan untuk melakukan tawar menawar (dan melakukan tempat penawaran dan permintaan) sehingga dengan demikian terbentuk harga. Pengertian pertama biasanya disebut dengan pengertian abstrak dan yang kedua disebut dengan pengertian abstrak.

Oleh sebab itu, sebagian ulama terkini mereka mendefinisikan Khiyar secara syar'i sebagai "Hak orang yang brakad dalam dalam membatalkan akad atau meneruskannya karena ada sebab-sebab secara syar'i yang dapat membatalkannya sesuai dengan kesepakatan ketika berakad". Khiyar sendiri terdiri dari beberapa macam di antaranya: Khiyar syarat, Khiyar majelis, dan Khiyar 'aib.

Khiyar Syarat ialah hak pilih yang ditetapkan bagi salah satu pihak yang berakad atau keduanya atau bagi orang lain untuk meneruskan atau membatalkan akad jual beli, selama masih dalam tenggang waktu yang ditentukan. Dalam tenggang waktu yang diisyaratkan itu dapat dilakukan pembatalan jual beli yang dengan sendirinya masing-masing pihak mengembalikan barang dan uang

\footnotetext{
${ }^{1}$ Masruru, Nanang Taufik. “Pandangan Hukum Islam Terhadap Pelaksanaan Khiyar”. Jakarta : Kencana, 2014, 4

${ }^{2}$ Masruru, Nanang Taufik. “Pandangan Hukum Islam Terhadap Pelaksanaan Khiyar”. Jakarta : Kencana, 2014, 4

${ }^{3}$ Masruru, Nanang Taufik. "Pandangan Hukum Islam Terhadap Pelaksanaan Khiyar”. Jakarta : Kencana, 2014,.15
} 
yang pernah diterimanya. Apabila tenggang waktu itu telah habis, maka dengan sendirinya hilanglah Khiyar, dan akad tersebut pun tidak dapat dibatalkan lagi. ${ }^{4}$

Khiyar Majelis adalah ialah hak pilih bagi kedua belah pihak (penjual atau pembeli) untuk meneruskan atau membatalkan akad selama keduanya berada dalam majelis akad dan belum berpisah badan.

Khiyar 'Aib adalah hak pembeli pembeli untuk meneruskan atau membatalkan akad jual beli tatkala terdapat suatu cacat pada objek yang diperjualbelikan. Sedangkan cacatnya itu tidak diketahui oleh pemiliknya.

Khiyar dalam transaksi jual beli di pasar saat ini belum bisa dikatakan sesuai, salah satunya di Pasar Wage, Kab. Nganjuk sebagai objek penelitian dengan alasan bahwa Pasar Nganjuk merupakan tmpat transaksi jual beli terbesar di kecamatan Nganjuk dan harganya dikenal miring. ${ }^{5}$

Dalam transaksi jual beli sembako di pasar Nganjuk proses Khiyar sudah diaplikasikan secara oleh beberapa pedagang sembako. Dan sebagian pedagang memahami kebenaran konsep Khiyar sesuai dengan hukum Islam. Ada beberapa pedagang yang mengaplikasikan proses Khiyar dengan beberapa kasus, misalnya ada seorang pembeli yang membeli beras dalam jumlah besar bisa dikatakan sampai dua karung, sesampai di rumah beras tersebut kotor dan terdapat beberapa kutu. Sesuai perjanjian barang yang dibeli jika terjadi kerusakan atau cacat maka boleh ditukar senilai harga beras tersebut atau uang kembali $100 \%$ karena dalam transaksi ini juga menjalin hubungan yang baik agar salah satu pihak tidak merasa dirugikan. Demikian transaksi jual beli tersebut bisa dikatakan Khiyar sudah diaplikasikan, tetapi tidak menutup kemungkinan Khiyar tidak diaplikasikan oleh pedagang lain. Berdasarkan permasalahan di atas maka penulis tertarik untuk melakukan penelitian lebih lanjut tentang Khiyar dalam jual beli yang saat ini terjadi di Pasar Wage Nganjuk dengan judul "Analisis Hukum Islam terhadap Khiyar dalam jual beli sembako di Pasar Wage Kabupaten Nganjuk".

Berdasarkan latar belakang tersebut di atas, maka fokus penelitian yang akan diajukan oleh peneliti adalah bagaimana bentuk dan proses penerapan Khiyar dalam jual beli sembako ditinjau dalam hukum Islam. Dengan tujuan penelitian untuk mengetahui bagaimana bentuk dan proses penerapan Khiyar dalam transaksi jual beli sembako di Pasar Wage Kabupaten Nganjuk.

\section{METODE PENELITIAN}

Dipandang dari prosedur aktivitas penelitian yang penulis lakukan untuk menyusun proposal ini, menunjukkan bahwa penulis menggunakan penelitian kualitatif. Penelitian kualitatif adalah penelitian yang bersifat deskriptif dan cenderung menggunakan analisis. Proses dan makna (perspektif subjek) lebih ditonjolkan dalam penelitian kualitatif. Landasan teori dimanfaatkan sebagai pemandu agar fokus penelitian sesuai dengan fakta di lapangan. Sesuai dengan jenis penelitian ini yaitu penelitian kualitatif, maka kehadiran peneliti di tempat penelitian mutlak diperlukan sebagai instrumen utama. Instrumen penelitian adalah semua alat yang digunakan untuk mengumpulkan, memeriksa, menyelidiki suatu masalah dalam penelitian. Peran peneliti sebagai pengamat partisipan dan kehadiran peneliti oleh subjek atau informan untuk meneliti mengenai transaksi jual beli dalam Khiyar di Pasar Wage Kabupaten Nganjuk

Adapun penelitian ini dilaksanakan di Pasar Wage Kabupaten Nganjuk, lokasi ini dinilai menarik peneliti karena mudah dijangkau dan aktivitas transaksi yang selalu padat sehingga memudahkan peneliti untuk melakukan penelitian. dimana pasar tersebut baru saja direnovasi menjadi lebih besar dan luas. Dan merupakan pasar tersebar di Kabupaten Nganjuk. Sumber data dalam penelitian ini menggunakan dua sumber data, yaitu sumber data primer didapatkan dari wawancara, sedangkan sumber data sekunder didapat dari hasil observasi dan dokumentasi. Sumber data dalam penelitian ini adalah beberapa pedagang sembako dan pembeli di Pasar Wage Kabupaten Nganjuk.

Teknik pengumpulan data dalam penelitian ini menggunakan wawancara, observasi dan juga dokumentasi, adapun teknis analisis data dalam penelitian ini menggunakan reduksi data, penyajian data, dan penarikan kesimpulan. Adapun uji keabsahan data dilakukan oleh peneliti sendiri sebagai

\footnotetext{
${ }^{4}$ Mardani. Fiqh Ekonomi Syariah: Fiqh Muamalah, Bandung: Gaya Media Pratama. 2012,105

${ }^{5}$ Mardani. Fiqh Ekonomi Syariah: Fiqh Muamalah, Bandung: Gaya Media Pratama. 2012, 44
} 
partisipan, bisa menggunakan data dari hasil wawancara dan juga data yang sudah dikumpulkan (foto, surat, maupun catatan khusus), apakah sesuai hasil wawancara dan hasil pengumpulan datanya. Jika sesuai maka data tersebut dianggap absah.

\section{HASIL DAN PEMBAHASAN \\ Gambaran Obyek Penelitian \\ Kondisi Pasar Wage Nganjuk}

Pasar Wage Nganjuk merupakan pasar yang telah ada sejak lama. Namun secara resmi pasar Nganjuk didirikan atau mulai dikelola oleh pemerintah pada tahun 1950. Pasar Nganjuk telah mengalami banyak kemajuan, dahulu ketika masyarakat masih menggunakan budaya tradisional Pasar Wage Nganjuk merupakan tempat yang disepakati oleh para penjual dan pembeli untuk mengadakan jual beli atau pertukaran barang. Pedagang di Pasar Wage Nganjuk dahulu kebanyakan adalah petani yang menjual hasil ladangnya. Saat ini pasar bukan lagi hanya sebagai tempat untuk menjual hasil ladang tetapi masyarakat mulai menyadari bahwa pasar merupakan tempat atau sumber untuk mendapatkan penghasilan dan berbisnis.

Jumlah pedagang terus mengalami penambahan. Mereka tidak hanya menyediakan barang untuk diperdagangkan namun ada pula yang memanfaatkan pasar sebagai ladang untuk menawarkan jasa, misalkan menawarkan pinjaman modal, Kredit rumah, Mobil, tabungan dana haji dll, selain itu juga menawarkan produk seperti HP, Kartu perdana, dari beberapa toko di luar Pasar Wage Nganjuk. Dahulu pasar diberi nama sesuai dengan hari pasaran, yaitu pasar beroperasi, dahulu mungkin Pasar Wage hanya buka pada hari pasaran wage sehingga diberi nama pasar wage sebagai pembeda dengan pasar yang lain. Seiring dengan perkembangan waktu dan pola pikir masyarakat terus mengalami perubahan sehingga sekarang pasar wage beroperasi secara harian selama tujuh hari dalam seminggu atau setiap hari. Pasar Wage Nganjuk merupakan pasar dengan hasil retribusi terbesar di Kabupaten Nganjuk.

\section{Struktur kepengurusan}

Pasar Wage Nganjuk salah satu Aset milik Pemerintah Kabupaten Nganjuk. Menejemen atau pengelolaan Pasar Wage Nganjuk sejak Januari 2017 berada di bawah tanggung jawab Dinas Perdagangan dan Perindustrian Kabupaten. Sebelum dialihkan menjadi tanggung jawab Dinas Perdagangan Dan Perindustrian Kabupaten Nganjuk Pasar Wage Nganjuk berada dibawah naungan DPPKAD (Dinas Pendapatan Pengelolaan Keuangan Dan Asset Daerah Kabupaten Nganjuk). Struktur kepengurusan merupakan silsilah manajemen dari Pasar Wage Nganjuk. Pasar Wage memiliki area yang cukup luas sehingga dalam pengelolaannya terdiri atas dua kantor manajemen yaitu Pasar Wage Nganjuk dan Pasar Wage Nganjuk yang masingmasing terdiri atas seorang koordinator, 5 orang petugas kebersihan, 7 orang petugas pungut 2 orang petugas administrasi. Dan 2 orang petugas keamanan. Masing-masing kantor tersebut akan mempertanggungjawabkan wewenang nya kepada kantor Dinas Perdagangan Dan Perindustrian Kabupaten Nganjuk. Pasar Wage Nganjuk memiliki dua kantor pengelola manajemen dikarenakan lokasi yang digunakan sebagai sarana dagang pasar wage sangat luas yaitu : 5981,9 m2 untuk Pasar Wage Nganjuk yang merupakan setengah dari luas keseluruhan bangunan di Pasar Wage Nganjuk. Dengan adanya pembagian wilayah menajemen tersebut tentu memiliki dampak positif dan negatif. Dampak positif dari pembagian tersebut adalah kegiatan manajemen menjadi lebih merata dan fokus sedangkan dampak negatifnya adalah dikhawatirkan akan menimbulkan perlakuan yang berbeda di antara keduanya mengingat tidak ada koordinasi antara Pasar Wage Nganjuk 1 dengan Pasar Wage Nganjuk 2 dan koordinator dari masing-masing pasar bertanggung jawab secara langsung kapada Dinas Perdagangan Dan Perindustrian Kabupaten Nganjuk.

\section{Letak geografis Pasar Wage Nganjuk}

Pasar Wage Nganjuk berada di kawasan jalan Ahmad Yani. Jalan Ahmad Yani merupakan pusat Kabupaten Nganjuk yang letaknya di selatan Alun-Alun Nganjuk. Jalan ini juga salah satu urat nadi perekonomian Kabupaten Nganjuk. Di kawasan ini berdiri toko banyak 
toko dengan beraneka produk yang ditawarkan juga beberapa swalayan. Di sini juga terdapat banyak bangunan lembaga keuangan di antaranya pegadaian UPC pasar wage, bank mandiri, BNI, BCA, CIMB Niaga, dan bank mandiri syariah. Setiap harinya jalan ini memiliki aktifitas yang padat mulai dari mereka yang akan bekerja, berangkat sekolah, atau bepergian. Tidak jauh dari jalan ini berdiri banyak kantor pemerintahan juga sekolah-sekolah melihat kondisi wilayah dari lokasi penelitian dapat diketahui bahwa Pasar Wage Nganjuk memiliki lokasi yang cukup strategis karena berdekatan dengan pemukiman yang padat penduduk selain itu juga berdekatan dengan pusat pemerintahan Kabupaten Nganjuk. Kondisi ini tentu memberikan dampak yang positif bagi para pedagang pasar karena memiliki jumlah pembeli yang cukup banyak. Yang mana pembeli tersebut tidak hanya dari penduduk lokal (asli), melainkan juga para pegawai, karyawan toko dan lain-lain.

Kondisi Pasar Wage Nganjuk tahun 2020 berbeda dari tahun sebelumnya, yang menjadi faktor utama perbedaan adalah adanya Covid-19 yang secara langsung sudah berdampak buruk bagi para pedagang dan pelaku pasar lainnya. Pasar Wage baru di Kabupaten Nganjuk, secara resmi telah beroperasi sepenuhnya yang di buka untuk umum. Meski dengan kondisi pasar wage yang baru, banyak pedagang yang mengeluhkan soal sepinya pasar, akibat banyak pelanggan yang enggan datang. Saat kunjungan Bupati Nganjuk Novi Rahman Hidayat di temani dengan Wakil Bupati Nganjuk Marhaen Djumadi, meresmikan Pasar Wage Nganjuk yang baru. Dalam peresmian itu Bupati Nganjuk juga meninjau lapak para pedagang. Dalam kunjungan nya banyak pedagang yang mengeluhkan terkait pemindahan pasar lama ke pasar Wage baru, terutama yang paling banyak dirasakan pedagang adalah dampak sepinya pengunjung. Beberapa pedagang mengatakan sepinya pengunjung, karena lokasi penempatan dagangan di pisahkan tidak seperti sebelumnya yang campur. Selain itu juga kondisi penempatan bangunan yang justru dinilai tidak terbuka, dan membuat pelanggan enggan masuk ke dalam lingkungan pasar yang baru. Sementara itu, Bupati Nganjuk Novi Rahman Hidayat menyebut, dalam tinjauannya di dalam pasar wage baru, masih banyak kios pasar yang belum ditempati pedagang, berbagai persoalan yang dikeluhkan pedagang ia terima untuk ditemukan solusinya, salah satunya menyebut jika pasar ini ketika siang hari pengap dan panas, meski telah secara resmi pindah, kenyataan di lapangan banyak pedagang yang enggan membuka kiosnya karena lantaran sepi dari pelanggan. Menurut pedagang pembeli lebih memilih ke pasar wage lama, yang saat ini masih di huni oleh 500 pedagang, karena dinilai lebih mudah mengakses dan mendapatkan barang-barang yang diperlukan. Para pedagang berharap, pemerintah segera memberikan solusi terbaik, agar sepinya pelanggan ini, tidak mematikan usaha mereka. ${ }^{6}$

\section{Sarana dan Prasarana}

Pasar yang merupakan salah satu tempat masyarakat dalam mengupayakan pemenuhan kebutuhan. Pedagang memanfaatkan pasar untuk memasarkan barang dagangannya yang berupa pangan, non pangan juga jasa-jasa lainnya. Pembeli memanfaatkan pasar untuk mendapatkan apa yang mereka perlukan. Dalam aktivitasnya yang berjalan untuk waktu yang lama tentunya diperlukan adanya sarana dan prasarana untuk mendukung kelancaran proses pertukaran tersebut. Berikut sarana dan prasarana yang ada di Pasar Wage Nganjuk. Pasar Wage Nganjuk berdiri diatas tanah seluas 7709,8 $\mathrm{m} 2$ dengan luas bangunan 5981,9 m2. Bangunan di dalam Pasar Wage Nganjuk bersifat permanen, namun ada beberapa tempat yang oleh pedagang dibangun kembali untuk kenyamanan dalam berdagang dan keamanan. Pasar Wage Nganjuk juga didukung dengan fasilitas yang cukup mumpuni seperti tempat parkir di 3 tempat yang dikelola oleh pihak Pasar Wage Nganjuk yaitu yang berada di depan kantor Pasar Wage Nganjuk, di gerbang barat bagian tengah dan juga di gerbang timur bagian utara. Akan tetapi tempat yang disediakan oleh pihak Pasar Wage Nganjuk tidak terlalu luas. Di mana masingmasing hanya dapat menampung \pm 30 kendaraan. Disebelah barat Pasar Wage Nganjuk juga ada beberapa penduduk yang telah membuka jasa penitipan kendaraan sehingga masyarakat merasa lebih tenang ketika meninggalkan kendaraannya untuk berdagang atau berbelanja. Akan tetapi

${ }^{6}$ Wawancara dengan petugas pengelola pasar wage Nganjuk, 25 Mei 2020 
beberapa pengunjung pasar juga ada yang memarkir kendaraannya di pinggir jalan sepanjang Pasar Wage Nganjuk di kelola oleh dinas perhubungan.

Untuk hari-hari tertentu dimana kondisi pasar sedang ramai terkadang hal ini menghambat kegiatan lalu lintas yang ada di kawasan tersebut. MCK yang berada di dua tempat yang masing-masing tempat terdiri atas 4 toilet. Dan juga sebuah TPS di pojok timur sebelah barat yang dikelola oleh Dinas Lingkungan Hidup Kabupaten Nganjuk. Pasar ini tidak menyediakan tempat ibadah karena tepat di barat pasar ini terdapat masjid yang cukup besar yaitu Masjid Baitus Sholihin. Mengingat lokasi pasar yang berada dipusat kota akses untuk menuju Pasar Wage Nganjuk cukup mudah. Beragam alat transportasi umum dapat digunakan, meliputi, becak, bemo, angkot, andong, bus, sepeda motor.

\section{Jumlah Pedagang}

Tercatat dalam pendataan Pasar Wage Nganjuk, pedagang yang ada di Pasar Wage Nganjuk adalah sejumlah 791 pedagang. Pedagang yang memiliki kios di Pasar Wage Nganjuk tidak hanya berasal dari kecamatan Nganjuk tetapi juga beberapa kecamatan di wilayah Kabupaten Nganjuk.

\section{Jumlah pedagang berdasarkan tempat berdagang}

\begin{tabular}{|l|l|}
\hline Jenis tempat berdagang & Jumlah pedagang \\
\hline Los & 567 pedagang \\
\hline Kios & 181 pedagang \\
\hline Dasaran & 43 pedagang \\
\hline Total & 791 pedagang \\
\hline
\end{tabular}

\section{Jalur Pembelian Barang Dagangan}

Pasar Wage Nganjuk tergolong sebagai pasar yang lengkap. Di Pasar Wage Nganjuk menyediakan segala jenis kebutuhan mulai dari bahan makanan, makanan, sembako, pakaian, tas, sepatu, asesoris, peralatan dapur, gerabah, mainan anak-anak, buah-buahan, obat-obatan dan lain-lain. Pedagang di Pasar Wage Nganjuk mendapatkan dagangan tersebut dari pabrik (produsen), pedagang besar (grosir), dari agen dan dari hasil produksinya sendiri. Dalam keputusan pengambilan barang dagangan ini tentunya akan mempengaruhi harga pokok pembelian barang dagangan. Dagangan yang dibeli langsung dari produsen (pabrik) tentunya akan lebih murah jika dibandingkan dengan dagangan yang dibeli dari grosir maupun agen atau sales. Di Pasar Wage Nganjuk banyak pedagang grosir yang memilih berkeliling menawarkan dagangannya kepada pedagang yang ada di Pasar Wage Nganjuk. Akan tetapi harganya tentu lebih mahal jika dibandingkan dengan pedagang mengambil sendiri dagangannya kepada pedagang besar.

Terkait dengan pengambilan barang dagangan ini tentunya memiliki kelebihan dan kelemahan. Misalnya Ketika pedagang mengandalkan sales yang datang ke pasar untuk memenuhi barang dagangannya maka dapat dipastikan produk yang diterima oleh seorang pedagang akan sama dengan produk yang diterima oleh pedagang lain yang membeli pada sales yang sama. Namun mengandalkan sales ini juga menguntungkan pedagang, di antaranya pedagang tidak perlu repot mendatangi lokasi produksi atau agen atau grosir, pedagang hanya perlu menunggu sales datang ke kiosnya untuk menawarkan dagangan kemudian pedagang dapat memilih sendiri barang yang akan dibeli untuk dijual kembali. Transaksi pembelian pada sales tidak mewajibkan pedagang untuk membayar tunai/lunas, beliau dapat melakukan pembayaran secara mengangsur. Ketika ditemukan barang cacat maka pedagang dibolehkan untuk menukar barang cacat tersebut dengan barang yang baru. Ketika pedagang memilih untuk datang langsung kepada produsen, pedagang besar atau agen pedagang akan mendapatkan harga yang lebih murah, selain itu pedagang akan lebih leluasa untuk memilih dagangannya. Beliau dapat mengambil dagangan yang berbeda dari dagangan milik pedagang lain sehingga bisa 
menjadi ciri khas pedagang tersebut. Di sisi lain ketika pedagang memutuskan untuk mengambil sendiri dagangannya maka pedagang harus memperhitungkan ongkos perjalanan dan juga biaya angkut barang yang dibeli tersebut. Transaksi antar pedagang ini biasanya merupakan transaksi tunai sehingga pedagang diharuskan membayar lunas dagangan yang dibeli. Tentu saja ketika pedagang memilih untuk datang langsung ke pedagang besar beliau akan mengambil barang dalam jumlah besar. Hal ini dilakukan agar tidak merugikan pedagang, mengingat ongkos yang dikeluarkan untuk mendatangi pedagang besar tersebut. Pemilihan pengambilan barang sangat berpengaruh pada harga pembelian barang dagangan yang akhirnya akan berdampak pada harga akhir yang diberikan kepada pembeli (konsumen).

Pedagang yang mendapatkan barang dagangan lebih murah dari pedagang lain tentu akan mendapatkan keuntungan yang lebih besar, mengingat dengan jumlah pedagang yang memiliki dagangan serupa tidak hanya satu dua orang maka pedagang tidak punya pilihan selain memberikan penawaran yang tidak jauh beda. Karena ketika pedagang mendapatkan barang dagangan dengan harga tinggi, kemudian mengharapkan keuntungan yang sama dengan pedagang yang memperoleh barang dagangan dengan harga lebih murah, maka pedagang akan menawarkan barang tersebut dengan harga yang tinggi kepada konsumen. Dalam hal ini konsumen dapat dipastikan akan memilih membeli kepada pedagang yang menawarkan dagangan dengan harga yang lebih murah, kemudian untuk pedagang yang menawarkan atau mematok dengan harga tinggi akan ditinggalkan oleh konsumen nya. Untuk menyiasati hal ini pedagang di Pasar Wage Nganjuk memilih untuk memadukan sumber perolehan barang tersebut, mereka memilih untuk mengambil dagangan pada sales dihari biasa kemudian akan mengambil dagangan sendiri ke produsen atau agen atau pedagang besar pada saat diperkirakan akan ramai pembeli (dagangan laku) misalkan untuk pedagang pakaian, tas, sepatu beliau akan mengambil sendiri dagangannya ketika menjelang puasa dan hari raya atau pada tahun ajaran baru anak sekolah. Hal ini tentu saja tidak berlaku untuk pedagang bahan makanan dan bahan pokok. Karena setiap hari konsumen membutuhkan barang tersebut dan dipastikan laku.

\section{Jalur Penjualan Barang Dagangan}

Dagangan yang telah diperoleh pedagang di Pasar Wage Nganjuk akan dijual kepada pedagang dan kepada konsumen akhir. Dagangan yang dijual kepada pedagang untuk dijual kembali bersifat grosir. Pembeli ( yang dimaksud pedagang yang akan menjual kembali ) ada yang datang dari sesama pedagang yang ada di Pasar Wage Nganjuk ada pula yang dari luar Pasar Wage Nganjuk dari pedagang tersebut akan dijual kembali kepada konsumen akhir baik melalui perdagangan menggunakan kios untuk menjajakan dagangannya atau menggunakan sistem keliling kampung. Pembeli ini mayoritas adalah ibu-ibu yang membeli di Pasar Wage Nganjuk untuk kemudian dijual kembali di wilayah tempat tinggalnya secara kredit, sistem ini biasanya berlaku untuk pakaian, selimut, seprai, sepatu, tas, dsb. Selain penjualan sistem kredit pedagang keliling juga menjual barang dagangannya secara tunai. Pembeli ini biasanya membeli untuk dijual kembali kepada orang lain secara kredit maupun tunai. Barang yang dibeli biasanya merupakan pesanan dari calon pembeli akhir. Selain penjualan dengan sesama pedagang atau untuk dijual kembali pedagang di Pasar Wage Nganjuk juga menjual dagangannya untuk pembeli akhir yaitu dengan sistem ecer atau pembelian dalam jumlah satuan. Pembeli akhir dapat berasal dari berbagai kalangan. Pembeli ini membeli barang bertujuan untuk dimanfaatkan sendiri. Harga yang diberikan pedagang di Pasar Wage Nganjuk untuk sesama pedagang atau pembelian untuk dijual kembali lebih murah dibandingkan dengan harga yang diberikan untuk konsumen akhir.

\section{Kondisi Persaingan Bisnis di Pasar Wage Nganjuk}

Dalam aktivitas perdagangan sehari-hari dalam pasar, tidak terlepas dari persaingan. Persaingan dalam bisnis adalah hal yang wajar, begitu pula dengan persaingan bisnis para pedagang Pasar Wage Nganjuk. Dari pengamatan yang penulis lakukan persaingan bisnis yang terjadi di Pasar Wage Nganjuk adalah persaingan yang tidak sehat karena terdapat praktik yang tergolong persaingan tidak sehat seperti banting harga dan monopoli tetapi secara keseluruhan 
praktik persaingan yang dilakukan oleh pedagang yang ada di dalam Pasar Wage Nganjuk dapat dikatakan berjalan dengan baik.

Pasar Wage Nganjuk memiliki beragam produk yang ditawarkan. Pedagang menjajakan dagangannya dalam kios-kios dan lapak-lapak ada juga pedagang keliling di pasar ini. Di dalam Pasar Wage Nganjuk setiap pedagang memiliki pelanggan masing-masing sehingga tidak ditemukan adanya perebutan pembeli antar pedagang. Pedagang tidak pernah memaksa pembeli untuk membeli dagangannya, karena sebagai pembeli memiliki kebebasan untuk menentukan produk yang dibeli dan membeli barang yang diperlukan dari pedagang manapun

\section{Penyajian Data Khiyar dalam Transaksi Jual Beli Sembako di Pasar Wage Kabupaten Ngajuk Pelaksanaan jual beli sembako secara grosir di Pasar Wage Kabupaten Nganjuk}

Ada 392 pedagang yang menjual sembako secara grosir dengan lokasi berjualan yang terpisah dan dengan ukuran toko yang berbeda. Untuk mengetahui pelaksanaan jual beli sembako secara grosir yang terjadi di Pasar Cindrawasih Kota Metro, peneliti mengadakan wawancara kepada 3 pedagang secara grosir yang peneliti anggap berpotensi untuk memberikan informasi, berikut 3 data pedagang sembako secara grosir sebagai berikut:

\begin{tabular}{|c|l|l|c|}
\hline No. & \multicolumn{1}{|c|}{ Nama pedagang } & \multicolumn{1}{|c|}{ Nama Toko } & Tahun Berdiri \\
\hline 1. & Ibu Astutik & Rahayu & 1999 \\
\hline 2. & Ibu Samiyem & Tidak Ada Nama & 1995 \\
\hline 3. & Ibu Darni & Tidak Ada Nama & 2005 \\
\hline 4. & Pak. Toni & Tidak Ada Nama & 2004 \\
\hline 5. & Pak Waskito & Barokah Jaya & 2000 \\
\hline 6. & Bu. Leginem & Tidak Ada Nama & 1994 \\
\hline 7. & Bu. Warti & Makmur Risky & 1990 \\
\hline 8. & Bu. Anggraini & Tidak Ada Nama & 2010 \\
\hline 9. & Mbah Waini & Tidak Ada Nama & 1992 \\
\hline 10. & Pak Cip & Rahayu Slamet & 1994 \\
\hline
\end{tabular}

Adapun dalam proses jual beli sembako secara grosir dilakukan dengan dua sistem jual beli yaitu sebagai berikut:

(1) Sistem Langsung

Adapun proses jual beli secara langsung adalah apabila ada calon pembeli datang, maka dipersilahkan masuk dan memilih sembako yang akan dibeli jika pembeli adalah pembeli biasa maksudnya adalah bukan pedagang eceran maka akan terjadi tawar menawar harga grosir dan setelah ada kesepakatan barang dan harga, maka transaksi jual beli pun berlangsung di ikuti penyerahan sembako dan nota pembelian dari pihak penjual dan uang dari pihak pembeli. Namun jika calon pembeli sudah menjadi langganan (pedagang sembako ecer, online) maka langsung menyebutkan jenis barang yang akan dibeli. Setelah terjadi kesepakatan mengenai jenis dan jumlah sembako maka tawar menawar harga dilakukan jika memang terjadi perubahan harga grosir dan setelah sepakat maka pihak penjual memberikan nota pembelian.

(2) Sistem Pemesanan

Pembelian dengan sistem pesanan adalah apabila barang yang dibeli tidak ada di toko namun stok di pedagang besar ada. Jika pembelian sembako dilakukan dengan sistem pesanan maka dalam proses memesan calon pembeli baru harus langsung mendatangi toko dan membawa contoh atau menyebutkan barang dan jumlah yang di inginkan. Setelah ada kesepakatan antara jumlah sembako dan jenis sembako maka penjual akan langsung mengkonfirmasi sembako pesanan kepada pedagang besar yang ada di Jakarta, kemudian jika sembako ada maka calon pembeli diberikan nota pembelian dengan pembayaran DP $10 \%$ sebagai tanda jadi pemesanan. Apabilacalon pembeli sudah 
menjadi langganan maka pemesanan bisa dilakukan via telpon dengan menyebutkan jenis sembako yang di inginkan. Jika sembako yang dipesan telah datang maka pihak penjual menghubungi pembeli via telepon dan baru memberikan nota ketika pemesan.

\section{Pelaksanaan hak Khiyar di pedagang sembako secara grosir di Pasar Wage Nganjuk}

Dalam jual beli, pemilihan atau Khiyar adalah suatu yang menjadi kebiasaan yang dilakukan oleh pembeli terhadap penjual. Islam sebagai agama rahmatan memiliki konsep "asas muamalah adalah kebolehan, kecuali ada larangan yang jelas dan ini tentunya berlaku pada setiap muamalah termasuk pemilihan (Khiyar) dalam jual beli. Tujuan adanya Khiyar adalah agar kedua belah pihak (baik penjual ataupun pembeli) tidak akan mengalami kerugian atau penyesalan setelah transaksi yang diakibatkan dari sebab-sebab tertentu dari proses jual beli yang dilakukan. Atau hal yang terkait mengenai barang ataupun harga. Berikut adalah penjelasan mengenai Khiyar dalam jual beli.

Khiyar merupakan salah satu hal yang sangat penting untuk diperhatikan dalam melaksanakan berbagai aktivitas bisnis, khususnya dalam persoalan jual beli. Saking pentingnya persoalan ini, maka para ulama fikih (fuqaha') membahasnya secara panjang lebar dalam pembahasan tersendiri atau setidaknya dalam sub pembahasan tersendiri pada bab buyu' (jual beli). Atas dasar itulah, maka dalam pembahasan kali ini, penulis membahas persoalan Khiyar baik dari aspek definisi Khiyar, dasar hukumnya, klasifikasinya, problematikanya, dampaknya serta hikmah disyari'atkannya Khiyar.

Dalam praktiknya, tidak sedikit orang merasa gelo (menyesal) dalam melakukan transaksi jual beli. Penyesalan tersebut dapat terjadi baik di pihak penjual maupun pihak pembeli. Penyesalan umumnya dapat diakibatkan oleh tidak adanya transparansi, teknik penjualan yang tidak optimal sampai persoalan kualitas barang yang ditransaksikan tidak sesuai dengan harapan, baik karena kesengajaan pihak penjual maupun karena ketidak cermatan, kurang hati-hati (tergesa-gesa) atau faktor-faktor lainnya dari pihak pembeli.

Padahal salah satu prinsip pokok dalam transaksi jual beli adalah harus didasari oleh sikap saling suka atau saling rida (Innamal bai' 'an taradin; hanya saja jual beli harus didasari saling meridai) sebagaimana dijelaskan dalam hadis Nabi. Atas dasar itulah, agama memberi kesempatan kepada kedua belah pihak yang melakukan transaksi atau akad jual beli untuk memilih antara dua kemungkinan, yaitu melangsungkan transaksi (akad) jual beli atau membatalkannya, atau yang sering disebut dengan Khiyar.

Pedagang grosir memberikan hak bagi pembeli untuk meneruskan ataupun membatalkan jual beli selama proses transaksi sedang berlangsung. Jika calon pembeli menyetujui harga dan jenis sembako yang dinginkan ada maka jadilah jual beli, dengan adanya penyerahan uang dari pihak pembeli dan barang dari pihak penjual. Namun jika pihak pembeli ingin membatalkan jual beli karena beberapa sebab maka solusi yang diterapkan berbeda-beda, berikut penjelasan berdasarkan hasil penelitian sebagai berikut:

Berdasarkan kedua sistem pembelian tersebut diketahui bahwa Ibu Astutik, Ibu Samiyem dan Ibu Darni dalam sistem pengembalian sembako antara penjuan dan pembeli harus ada kesepakatan dan perjanjian terlebih dahulu dengan penjual, pengembalian sembako harus karena adanya rusak saja dan pengembalian sembako rusak untuk pembeli biasa adalah maksimal tiga hari sedang untuk pedagang eceran tidak boleh lebih dari 7 hari karena dalam setiap 1 minggu pedagang akan belanja dan mereturn barang yang mengalami rusak, namun waktu dapat diperpanjang apabila alasan yang diberikan oleh pihak pembeli dapat diterima oleh penjual. Penjual mengatakan bahwa dalam sistem pengembalian sembako karena rusak maka pengembalian bisa langsung dilakukan tanpa adanya suatu perjanjian diawal karena adanya kebijakan barang rusak bisa dipulangkan tanpa harus ada suatu perjanjian terlebih dahulu sebagai wujud toleransi kepada sesama pedagang, karena kebanyakan yang membeli sembako grosir adalah pedagang eceran. Pengembalian tidak bisa dilakukan dalam bentuk uang, melainkan dilakukan dalam bentuk penukaran barang. Alasan penjual tidak memperbolehkan pengembalian dalam bentuk uang adalah: 
1) Menurut pedagang uang yang sudah diterima, sudah masuk dalam catatan pembukuan sehingga sudah tidak bisa diambil kembali karena akan mengganggu catatan pembukuan.

2) Pengembalian juga menambahkan bahwa pembatalan pembelian dengan uang akan menjadi resiko besar seorang pedagang karena sembako yang seharusnya sudah laku mengendap di toko lebih lama.

Berdasarkan hasil wawancara yang telah peneliti dapatkan dari ke tiga pedagang sembako bahwa ketika ada pembeli yang mensyaratkan pengembalian sembako dengan adanya penambahan waktu sebagai pertimbangan untuk memilih meneruskan ataupun membatalkan jual beli maka tidak diperbolehkan, hal ini dilakukan karena sebelum transaksi jual beli disahkan pihak calon pembeli diberikan kebebasan memilih sembako dan diberikan keputusan untuk meneruskan ataupun membatalkan pembelian jika ternyata selama proses transaksi ada yang tidak sesuai dengan keinginannya baik dari jenis sembako maupun harga sembako. Jika ternyata telah terjadi serah terima uang dan barang maka transaksi dianggap sah dan pembatalan hanya boleh dilakukan karena adanya sembako yang rusak saja.

Berdasarkan hasil wawancara di atas dapat dipahami bahwa pembeli yang mayoritas adalah pedagang sembako eceran sering kali mengalami kerugian akibat kebijakan yang dibuat secara sepihak oleh pedagang sembako grosir tanpa adanya kesepakatan terlebih dahulu antara kedua belah pihak. Meski kerugian terlihat tidak terlalu besar namun bagi pedagang jilbab eceran, kerugian tersebut sangat berarti. Meski begitu pembeli tidak bisa berbuat terlalu banyak karena pembeli sangat membutuhkan jasa pedagang jilbab grosir meski sebenarnya pembeli sangat kecewa dengan kebijakan yang telah diberikan oleh pedagang. Namun demikian jika pembatalan karena sembako mengalami aib maka pihak penjual masih memberikan tambahan waktu pengembalian jilbab meski sudah melewati batas maksimal pengembalian sebagai wujud toleransi kepada sesama pedagang. ${ }^{7}$

Hak Pilih Ketika Barang Terdapat Kerusakan (Khiyar Aib): Toko Rahayu, Titipan dari grosir sembako yang dibeli atau dipesan mengalami aib (kerusakan) maka solusi yang diberikan adalah memberikan hak sepenuhnya kepada pembeli apakah akan meneruskan ataupun membatalkan jual beli. Namun jika pembeli memilih membatalkan jual beli barang yang terdapat aib maka diperbolehkan dengan ketentuan sudah ada kesepakatan diawal, namun dalam bentuk tukar barang, jika pembatalan berasal dari masyarakat biasa, maka waktu yang diberikan adalah maksimal 3 hari, namun jika pembatalan berasal dari pedagang jilbab eceran, rumahan atau pedagang jilbab online, maka waktu yang diberikan maksimal adalah 7 hari. Adapun ketentuan penukaran barang adalah yang ditetapkan adalah sebagai berikut:

1) Menukarkan sembako yang telah dibeli dengan sembako yang sama harganya.

2) Menukarkan sembako dengan sembako lain yang harganya lebih mahal sehingga pembeli harus membayar kekurangan uang.

3) Menukarkan sembako dengan sembako lain yang harganya lebih murah, yang dalam hal ini seharusnya pihak penjual mengembalikan sisa uang kepada pembeli, namun penjual menolak mengembalikan sisa uang tersebut. Penjual telah memberikan solusi yang dapat dilakukan yaitu sisa uang yang seharusnya dikembalikan dibelikan jilbab lain sehingga yang menambah uang adalah pihak pembeli. ${ }^{8}$

Hak pilih ketika pembeli melihat barang yang belum ia lihat sebelumnya (Khiyar Ruyah). Ketika sembako yang dipesan telah dilihat oleh pemesan (pembeli) maka pihak penjual memberikan pilihan jika ingin meneruskan ataupun membatalkan jual beli jika ternyata pembeli memilih membatalkan pesanan maka solusi yang bisa diambil oleh pihak pembeli memberikan kebebasan bagi pihak pembeli jika ingin membatalkan jual beli tersebut. Jika ternyata pihak pembeli memilih membatalkan jual beli maka uang muka yang telah dibayarkan yaitu sebesar $10 \%$ dianggap hangus. Hal ini dikarenakan uang tersebut dijadikan sebagai uang ganti rugi atas pembatalan yang telah dilakukan oleh bu. Astutik juga menambahkan bahwa jika pembeli tidak ingin uang DP hangus maka sembako harus tetap diambil. Namun jika kesalahan berasal dari

\footnotetext{
${ }^{7}$ Wawancara dengan pedagang sembako Pasar Wage Nganjuk tanggal 25 Mei 2020

${ }^{8}$ Wawancara dengan pedagang sembako Pasar Wage Nganjuk tanggal 25 Mei 2020
} 
pihak pedagang besar maka pembeli diperbolehkan melakukan penukaran sembako yang tidak sesuai dengan contoh yang diperlihatkan. ${ }^{9}$

Hak pilih yang diberikan ketika ada pembeli yang mensyaratkan pengembalian sembako (Khiyar Syarat. )Berdasarkan hasil wawancara yang telah peneliti dapatkan dari ke tiga pedagang sembako bahwa ketika ada pembeli yang mensyaratkan pengembalian sembako dengan adanya penambahan waktu sebagai pertimbangan untuk memilih meneruskan ataupun membatalkan jual beli maka tidak diperbolehkan, hal ini dilakukan karena sebelum transaksi jual beli disahkan pihak calon pembeli diberikan kebebasan memilih sembako dan diberikan keputusan untuk meneruskan ataupun membatalkan pembelian jika ternyata selama proses transaksi ada yang tidak sesuai dengan keinginannya baik dari jenis jilbab maupun harga sembako. Jika ternyata telah terjadi serah terima uang dan barang maka transaksi dianggap sah dan pembatalan hanya boleh dilakukan karena adanya jilbab yang rusak saja. Adapun alasan yang kemukakan adalah sebagai persyaratan pengembalian sembako jika bukan karena cacat sangatlah beresiko, hal ini dikarenakan jika pembeli memutuskan pembatalan jual beli maka akan terjadi penumpukan stok barang lama yang di khawatirkan tidak akan laku karena telah ada model sembako yang baru. ${ }^{10}$

Jual beli dan pengaplikasian yang dilakukan oleh Bu. Darmi adalah: ketika penjual menawarkan sebuah barang adalah dengan menunjukkan beberapa pilihan barang. Jika terdapat barang yang sama dengan merk yang berbeda maka penjual langsung memberitahu kelebihan dan kekurangan barang tersebut. Dan pembeli bisa menentukan mana barang yang akan dijadikan hak milik. Penjual juga memberi alternatif dengan menjual utuh atau separo. Dengan demikian penjual sudah melakukan transaksi secara transparan dan sudah sesuai dengan syariat Islam dan tidak ada pihak yang dirugikan. Penjual mengatakan bahwa dalam sistem pengembalian sembako karena rusak maka pengembalian bisa langsung dilakukan tanpa adanya suatu perjanjian di awal karena adanya kebijakan barang rusak bisa dipulangkan tanpa harus ada suatu perjanjian terlebih dahulu sebagai wujud toleransi kepada sesama pedangang, karena kebanyakan yang membeli sembako grosir adalah padagang eceran. ${ }^{11}$

Transaksi jual beli dan pengaplikasian Khiyar yang dilakukan oleh Pak. Toni adalah dengan menjual barang secara grosir. Jika membeli dengan jumlah yang melebihi satuan lusin maka penjual akan memberi harga yang berbeda kepada pelanggan. Pedagang grosir grosir memberikan hak bagi pembeli untuk meneruskan ataupun membatalkan jual beli selama proses transaksi sedang berlangsung. Jika calon pembeli menyetujui harga dan jenis sembako yang dinginkan ada maka jadilah jual beli, dengan adanya penyerahan uang dari pihak pembeli dan barang dari pihak penjual. Namun jika pihak pembeli ingin membatalkan jual beli karena beberapa sebab maka solusi yang diterapkan berbeda-beda.

Sistem jual beli yang dilakukan oleh bu. Leginem sangat menyimpang jauh dengan aplikasi Khiyar, karena bu. Leginem termasuk orang jaman dahulu dan masih menjual barang yang masih lama sehingga tidak memperhatikan kualitas barang yang dijual. Berdasarkan hasil wawancara di atas dapat dipahami bahwa pembeli yang mayoritas adalah pedagang sembako eceran sering kali mengalami kerugian akibat kebijakan yang dibuat secara sepihak oleh pedagang sembako grosir tanpa adanya kesepakatan terlebih dahulu antara kedua belah pihak. Meski kerugian terlihat tidak terlalu besar namun bagi pedagang jilbab eceran, kerugian tersebut sangat berarti. Meski begitu pembeli tidak bisa berbuat terlalu banyak karena pembeli sangat membutuhkan jasa pedagang jilbab grosir meski sebenarnya pembeli sangat kecewa dengan kebijakan yang telah diberikan oleh pedagang. Namun demikian jika pembatalan karena sembako mengalami aib maka pihak penjual masih memberikan tambahan waktu pengembalian sembako meski sudah melewati batas maksimal pengembalian sebagai wujud toleransi kepada sesama pedagang. ${ }^{12}$

\footnotetext{
${ }^{9}$ Wawancara dengan pedagang sembako Pasar Wage Nganjuk tanggal 25 Mei 2020

${ }^{10}$ Wawancara dengan pedagang sembako Pasar Wage Nganjuk tanggal 25 Mei 2020

${ }^{11}$ Wawancara dengan pedagang sembako Pasar Wage Nganjuk tanggal 25 Mei 2020

${ }^{12}$ Wawancara dengan pedagang sembako Pasar Wage Nganjuk tanggal 25 Mei 2020
} 
Jual beli sembako yang ada di took Pak Waskito sudah menjadi kebutuhan masyarakat. Hal ini terlihat jelas dengan keadaan masyarakat yang setiap hari pastinya memerlukan kebutuhan sembako untuk memenuhi kehidupan sehari-hari. Ucapan yang digunakan dalam jual beli tersebut dilakukan secara lisan tanpa saksi maupun dalam bentuk tertulis. Serta tidak ada ketentuan yang mengikat antara penjual sembako dengan pembeli. Sehingga penjual bisa menjual sembako kepada siapa saja tanpa keadaan mengikat antara pembeli dan penjual. Dari pengamatan yang terjadi antara penjual sembako dan pembeli terdapat ucapan ketika antara kedua belah pihak melaksanakan transaksi jual beli sembako misal "Pak saya beli berasnya ya $12 \mathrm{Kg}$ uangnya minggu depan ya jika saya mengambil sembako lagi" kemudian pembeli mengatakan "Iya tidak apa-apa uangnya minggu depan". Transaksi pembayaran yang dilakukan antara penjual dan pembeli sembako tidak dilakukan secara langsung akan tetapi terdapat penundaan dalam pembayaran yang dilakukan dan sudah disepakati oleh kedua belah pihak. Praktik jual beli yang dilakukan oleh masyarakat di took Pak Waskito bermacam-macam bentuknya. Dalam pengalaman yang dilakukan oleh pihak penjual tentunya sudah hal yang tidak asing lagi bagi penjual sembako dalam melayani para pembeli. Penjual memberikan model pelayanan kepada pembeli-pembeli sembako tersebut ketika melaksanakan jual beli. Ada beberapa model dalam melayani jual beli yang dilakukan oleh penjual sembako antara lain:

Pesan Antar Model pelayanan yang dilakukan penjual-penjual sembako yang pertama adalah pesan antar, ketika pembeli memesan melalui via suara atau SMS untuk meminta agar barang yang dipesan untuk diantar ke rumah pembeli, maka penjual sembako dengan siap menghantar barang-barang tersebut dengan kendaraan yang dipunyai. Hal ini dilakukan oleh penjual sembako agar pembeli merasa nyaman dengan pelayanan yang diberikan olehnya. Dalam pelayanan pesan antar ini biasanya para pembeli yang membeli barang yang sekiranya banyak dan tidak bisa membawa dengan kendaraan motor maka pembeli tersebut meminta tolong agar barang yang dibeli bisa dihantar melalui kendaraan mobil dari pemilik penjual sembako. Dilihat dari pengamatan yang dilakukan oleh penjual sembako dapat dilihat model pelayanan pesan antar yang diberikan tidak menutup kemungkinan salah satu bentuk strategi pemasaran yang dapat dikatakan cukup baik, dengan tujuan agar pembeli-pembeli tersebut mempunyai kepuasan yang baik ketika belanja di rumah penjual sembako tersebut.

Pembeli langsung datang ke rumah penjual Model pelayanan yang seperti ini biasanya dilakukan oleh pembeli yang sekiranya bahan sembako yang ia beli hanya sedikit. Contoh, apabila penjual hanya membeli minyak satu kardus maka pembeli tersebut datang ke rumah penjual sembako secara langsung tanpa pesan lewat SMS atau melalui via suara. Karena barang yang dibeli sekiranya bisa dibawa sendiri tanpa bantuan dari pihak penjual sembako tersebut untuk mengantarkan barang tersebut ke rumah pembeli. ${ }^{13}$

Dalam praktiknya yang terjadi di kios Bu. Anggraini pembeli mendatangi penjual untuk membeli sembako. Pembeli membeli sembako dengan sistem kredit dan membayarnya berangsur-angsur. Akan tetapi harga yang dibayar tidak sesuai dengan kesepakatan awal. Sebagai contoh: jual beli sembako terjadi pada bulan Agustus, sedang bulan jatuh tempo adalah bulan Agustus hanya waktu pembayaran 2 minggu kemudian. Pada awal transaksi bulan Agustus harga sembako seperti rokok Rp. 15.000, kemudian pada saat jatuh tempo yakni bulan Agustus, ternyata harga mengalami penurunan menjadi Rp. 13.000. Maka pembeli berkewajiban membayar barang sembako seharga kesepakatan awal Rp. 15.000. jika yang terjadi demikian, jelas hal tersebut bisa dibilang wajar serta dibenarkan dalam praktiknya. Karena harga tersebut sesuai dengan harga pada saat terjadi transaksi atau kesepakatan awal. Namun jika kasusnya seperti ini, pada pertengahan transaksi, harga mengalami kenaikan menjadi Rp. 16.000. kemudian pada saat jatuh tempo harga mengalami penurunan menjadi Rp. 13.000. Karena harga pernah pada 47 posisi Rp. 16.000, serta harga tersebut merupakan harga tertinggi dari harga rokok. Maka, pembeli berkewajiban membayar rokok dengan harga Rp.16.000, karena harga rokok naik. Meski harga rokok pada akhirnya turun pada saat jatuh tempo. Hal itu tidak berpengaruh pada perjanjian yang telah disepakati. Bahwa harga tertinggi

\footnotetext{
${ }^{13}$ Wawancara dengan pedagang sembako Pasar Wage Nganjuk tanggal 25 Mei 2020
} 
yang digunakan sebagai dasar dari perhitungan pembayaran sembako. Terlepas dari benar atau salah, bagi penjual praktek yang demikian dirasa sudah sesuai dengan alasan. Jual beli itu terjadi karena sudah adanya kesepakatan antara kedua belah pihak.14

Di toko Pak Cip dijual dengan eceran yang selisih harganya relatif tinggi dari pada dengan membeli sembako yang borongan. Harga borongan dijual dengan harga jika pembeli menginginkan memilih sendiri jenis sembako tersebut. Dalam jual beli borongan ini pembeli cenderung berspekulasi atas barang yang mereka beli, kadang mereka dapat bagus dan tidak jarang pula para pembeli mendapatkan barang yang jelek serta mengecewakan Para pembeli dengan begitu merasa dibohongi walaupun dijual dengan harga yang lebih murah dari harga jual per biji. Sebagaimana yang telah penyusun jelaskan pada pembahasan sebelumnya bahwa gharar adalah jual beli yang mengandung tipu daya yang merugikan salah satu pihak karena barang yang diperjualbelikan tidak dapat dipastikan adanya, atau tidak dapat dipastikan jumlah dan ukurannya, atau karena tidak mungkin dapat diserahterimakan. ${ }^{15}$

\section{Pembahasan}

\section{Bentuk dan proses penerapan Khiyar dalam jual beli sembako di Pasar Wage Nganjuk.}

Setelah dilakukan penelitian ke Pasar Wage Nganjuk terhadap beberapa pedagang sembako baik eceran ataupun grosir peneliti menguraikan kesimpulan dari hasil penelitian. Sejauh ini ada beberapa pedagang yang belum mengetahui apa yang dimaksud dengan transaksi jual beli dengan pengaplikasian Khiyar. Karena ada beberapa pedagang yang ingin memperoleh keuntungan dengan tidak mempertimbangkan kepuasan pembeli. ${ }^{16}$

Pada kegiatan transaksi jual beli sembako secara grosir di ketahui bahwa dalam akad mengenai sistem pengembalian sembako yaitu pengembalian harus didasarkan atas perjanjian lisan. Jika ditemukan sembako aib maka solusi sudah disiapkan oleh pihak penjual yaitu penjual telah menentukan solusi sejak awal jika terdapat pengembalian sembako tanpa adanya kesepakatan antara penjual dan pembeli. hal ini tidak sesuai dengan salah satu syarat aqid yang dikemukakan oleh "Mazhab Maliki yaitu "keduanya dalam keadaan sukarela, jual beli berdasarkan paksaan adalah tidak sah". Senada dengan mazhab maliki, mazhab Hambali juga berpendapat bahwa salah satu syarat aqid adalah "Masing-masing aqid harus saling meridhai, yaitu tidak ada unsur paksaan kecuali dikehendaki oleh mereka yang memiliki otoritas untuk memaksa, seperti hakim atau penguasa". ${ }^{17}$

Berikut adalah beberapa praktik Khiyar di Pasar Wage Nganjuk yang dilakukan oleh beberapa pedagang sembako baik secara grosir atau eceran :

(1) Jual beli sembako yang diterapkan di toko Bu Samiyem,

Dalam sistem pengembalian sembako antara penjual dan pembeli harus ada kesepakatan dan perjanjian terlebih dahulu dengan penjual, pengembalian sembako harus karena adanya rusak saja dan pengembalian sembako rusak untuk pembeli biasa adalah maksimal tiga hari sedang untuk pedagang eceran tidak boleh lebih dari 7 hari karena dalam setiap 1 minggu pedagang akan belanja dan meretur barang yang mengalami rusak, namun waktu dapat diperpanjang apabila alasan yang diberikan oleh pihak pembeli dapat diterima oleh penjual. ${ }^{18}$

Penjual mengatakan bahwa dalam sistem pengembalian sembako karena rusak maka pengembalian bisa langsung dilakukan tanpa adanya suatu perjanjian diawa lkarena adanya kebijakan barang rusak bisa dipulangkan tanpa harus ada suatu perjanjian terlebih dahulu sebagai wujud toleransi kepada sesama pedangang, karena kebanyakan yang membeli sembako grosir adalah padagang eceran. Pengembalian tidak bisa dilakukan dalam bentuk uang, melainkan dilakukan dalam bentuk penukaran barang. ${ }^{19}$

\footnotetext{
${ }^{14}$ Wawancara dengan pedagang sembako Pasar Wage Nganjuk tanggal 25 Mei 2020

${ }^{15}$ Wawancara dengan pedagang sembako Pasar Wage Nganjuk tanggal 25 Mei 2020

${ }^{16}$ Hasil penelitian kepada pedagang sembako di Pasar Wage Nganjuk, Tgl 25 Mei 2020

${ }^{17}$ Hasil penelitian kepada pedagang sembako di Pasar Wage Nganjuk, Tgl 25 Mei 2020

${ }^{18}$ Hasil penelitian kepada pedagang sembako di Pasar Wage Nganjuk, Tgl 25 Mei 2020

${ }^{19}$ Hasil penelitian kepada pedagang sembako di Pasar Wage Nganjuk, Tgl 25 Mei 2020
} 
Pengaplikasian yang dilakukan dalam transaksi jual beli di toko bu Samiyem sudah baik dan sesuai proses Khiyar. Antara penjual dan pembeli sudah sama-sama memahami tentang resiko dan keuntungan yang didapatkan. Menurut peneliti jika pengaplikasian Khiyar dilakukan secara konsisten akan menjadi relasi yang baik dengan jangka waktu yang lama. ${ }^{20}$

(2) Jual beli dan pengaplikasian yang dilakukan oleh Bu Darmi

Sistem yang diterapkan dalam transaksi ini adalah ketika penjual menawarkan sebuah barang adalah dengan menunjukkan beberapa pilihan barang. Jika terdapat barang yang sama dengan merk yang berbeda maka penjual langsung memberitahu kelebihan dan kekurangan barang tersebut. Dan pembeli bisa menentukan mana barang yang akan dijadikan hak milik. Penjual juga memberi alternative dengan menjual utuh atau separo. Dengan demikian penjual sudah melakukan transaksi secara transparan dan sudah sesuai dengan syariat Islam dan tidak ada pihak yang dirugikan.

Penjual mengatakan bahwa dalam sistem pengembalian sembako karena rusak maka pengembalian bisa langsung dilakukan tanpa adanya suatu perjanjian diawal karena adanya kebijakan barang rusak bisa dipulangkan tanpa harus ada suatu perjanjian terlebih dahulu sebagai wujud toleransi kepada sesama pedagang, karena kebanyakan yang membeli sembako grosir adalah pedagang eceran. ${ }^{21}$ Memang dalam kesepakatan ini perjanjian dilakukan secara flexible tetapi ada baiknya jika kesepakatan ini diucapkan diawal agar penjual dan pembeli tidak ada komplain di belakang.

(3) Transaksi jual beli dan pengaplikasian Khiyar yang dilakukan oleh Pak Toni

Pengaplikasian Khiyar di toko ini adalah dengan menjual barang secara grosir. Jika membeli dengan jumlah yang melebihi satuan lusin maka penjual akan memberi harga yang berbeda kepada pelanggan. Pedagang grosir memberikan hak bagi pembeli untuk meneruskan ataupun membatalkan jual beli selama proses transaksi sedang berlangsung. Jika calon pembeli menyetujui harga dan jenis sembako yang dinginkan ada maka jadilah jual beli, dengan adanya penyerahan uang dari pihak pembeli dan barang dari pihak penjual. Namun jika pihak pembeli ingin membatalkan jual beli karena beberapa sebab maka solusi yang diterapkan berbeda-beda. Dan harga yang ditawarkan oleh pedagang tidak sama disesuaikan dengan keadaan yang terjadi. Yang mempengaruhi perbedaan harga biasanya dipicu seperti adanya Hari Raya Idul Fitri dan kenaikan harga BBM. ${ }^{22}$

Menurut peneliti pengaplikasian Khiyar yang dilakukan oleh pedagang sudah benar dan pedagang juga transparan dalam menjual produk dagangannya. Tetapi ada baiknya pedagang juga menjelaskan terhadap pembeli jika barang yang diterima dalam keadaan rusak atau kadaluarsa harga nya tidak harus sama sesuai kesepakatan awal. Karena jika pembeli sudah membawa barang dagangannya pembeli tidak akan kecewa. Dan pedagang juga bisa memberikan pilihan harga lain jika barang yang diterima pembeli tidak sesuai dengan keinginan. 23

(4) Sistem Jual Beli dalam pengaplikasian Khiyar di toko Bu Leginem

Sistem jual beli yang dilakukan oleh bu. Leginem sangat menyimpang jauh dengan aplikasi Khiyar, karena bu. Leginem termasuk orang jaman dahulu dan masih menjual barang yang masih lama sehingga tidak memperhatikan kualitas barang yang dijual. Berdasarkan hasil wawancara di atas dapat dipahami bahwa pembeli yang mayoritas adalah pedagang sembako eceran sering kali mengalami kerugian akibat kebijakan yang dibuat secara sepihak oleh pedagang sembako grosir tanpa adanya kesepakatan terlebih dahulu antara kedua belah pihak. Meski kerugian terlihat tidak terlalu besar namun bagi pedagang sembako eceran, kerugian tersebut sangat berarti. Meski begitu pembeli tidak bisa berbuat terlalu banyak karena pembeli sangat membutuhkan jasa pedagang sembako grosir meski sebenarnya pembeli sangat kecewa dengan kebijakan yang telah diberikan

\footnotetext{
${ }^{20}$ Hasil penelitian kepada pedagang sembako di Pasar Wage Nganjuk, Tgl 25 Mei 2020

${ }^{21}$ Hasil penelitian kepada pedagang sembako di Pasar Wage Nganjuk, Tgl 25 Mei 2020

${ }^{22}$ Hasil penelitian kepada pedagang sembako di Pasar Wage Nganjuk, Tgl 25 Mei 2020

${ }^{23}$ Hasil penelitian kepada pedagang sembako di Pasar Wage Nganjuk, Tgl 25 Mei 2020
} 
oleh pedagang. Namun demikian jika pembatalan karena sembako mengalami aib maka pihak penjual masih memberikan tambahan waktu pengembalian sembako meski sudah melewati batas maksimal pengembalian sebagai wujud toleransi kepada sesama pedagang. 24

Menurut peneliti pengaplikasian jual beli sudah saatnya dihentikan karena sudah banyak penyimpangan yang dilakukan. Memang toko bu. Leginem sudah berdiri sejak lama tetapi sebaiknya semakin lama usaha berdiri semakin baik pula pelayanannya. Karena toko legendaris sampai saat ini juga masih diminati banyak pembeli. Dengan memperhatikan kualitas barang dagangan maka kepuasan pembeli juga semakin meningkat.

(5) Jual beli dan pengaplikasian Khiyar di toko Pak Waskito

Jual beli sembako yang ada di took Pak Waskito sudah menjadi kebutuhan masyarakat. Hal ini terlihat jelas dengan keadaan masyarakat yang setiap hari pastinya memerlukan kebutuhan sembako untuk memenuhi kehidupan sehari-hari. Ucapan yang digunakan dalam jual beli tersebut dilakukan secara lisan tanpa saksi maupun dalam bentuk tertulis. Serta tidak ada ketentuan yang mengikat antara penjual sembako dengan pembeli. Sehingga penjual bisa menjual sembako kepada siapa saja tanpa keadaan mengikat antara pembeli dan penjual. Dari pengamatan yang terjadi antara penjual sembako dan pembeli terdapat ucapan ketika antara kedua belah pihak melaksanakan transaksi jual beli.$^{25}$

Transaksi ini sangat umum terjadi di pasar Wage Nganjuk karena pedagang dengan leluasa menjual barang dagangannya dan pembeli dengan leluasa memilih. Ada baiknya jika penjual lebih transparan dengan barang yang dijual dan harga yang ditawarkan jika pembeli membeli dalam jumlah banyak atau grosir. Sehingga harga yang ditawarkan tidak sama dengan yang ditawarkan dengan pembelian dengan jumlah rata-rata. ${ }^{26}$

(6) Pengaplikasian Khiyar di toko sembako Pak Cipto

Di toko Pak Cipto dijual dengan eceran yang selisih harganya relatif tinggi dari pada dengan membeli sembako yang borongan. Harga borongan dijual dengan harga jika pembeli menginginkan memilih sendiri jenis sembako tersebut. Dalam jual beli borongan ini pembeli cenderung berspekulasi atas barang yang mereka beli, kadang mereka dapat bagus dan tidak jarang pula para pembeli mendapatkan barang yang jelek serta mengecewakan

Para pembeli dengan begitu merasa dibohongi walaupun dijual dengan harga yang lebih murah dari harga jual per biji. Sebagaimana yang telah penyusun jelaskan pada pembahasan sebelumnya bahwa gharar adalah jual beli yang mengandung tipu daya yang merugikan salah satu pihak karena barang yang diperjualbelikan tidak dapat dipastikan adanya, atau tidak dapat dipastikan jumlah dan ukurannya, atau karena tidak mungkin dapat diserahterimakan.

Praktik jual beli ini seperti seharusnya sudah tidak terjadi di pasar atau dimanapun dikarenakan banyak sekali konsumen yang merasa tidak puas dengan pelayanan dari pedagang. Seharusnya pedagang banyak membenahi sistem transaksinya karena jika tidak kerugian juga akan menimpa pedagang, karena banyaknya toko yang lain yang lebih bagus dan memiliki kualitas barang yang baik pula. Serta praktik jual beli seperti ini juga sangat menyimpang dari ajaran Islam

\section{Manfaat yang diperoleh dengan penerapan Khiyar dalam proses jual beli di Pasar Wage} Kabupaten Nganjuk

Tujuan adanya Khiyar adalah agar kedua belah pihak (baik penjual ataupun pembeli) tidak akan mengalami kerugian atau penyesalan setelah transaksi yang diakibatkan dari sebabsebab tertentu dari proses jual beli yang dilakukan. Atau hal yang terkait mengenai barang

\footnotetext{
${ }^{24}$ Hasil penelitian kepada pedagang sembako di Pasar Wage Nganjuk, Tgl 25 Mei 2020

${ }^{25}$ Hasil penelitian kepada pedagang sembako di Pasar Wage Nganjuk, Tgl 25 Mei 2020

${ }^{26}$ Hasil penelitian kepada pedagang sembako di Pasar Wage Nganjuk, Tgl 25 Mei 2020
} 
ataupun harga. Tentunya dalam bisnis, Khiyar adalah hal yang perlu dipertimbangkan dan juga dipahami, baik oleh penjual ataupun pembeli. Khiyar dalam konteks jual beli bisa memiliki beberapa maksud. Hal ini diantaranya adalah hak memilih yang diberikan kepada dua belah pihak (penjual dan pembeli). Penjual dan pembeli memiliki hak yang sama untuk melangsungkan jual beli serta mengikuti syarat-syarat jual beli.

Setiap aturan islam pasti ada hikmah dan orientasi pemecahan masalah yang dapat diselesaikan. Tentu begitupun dengan adanya aturan Khiyar dalam proses transaksi jual beli. Dengan adanya aturan Khiyar, dapat di ambil beberapa hikmah yang luas. Hikmah pengaplikasian Khiyar dalam bertransaksi adalah sebagai berikut:

(1) Manfaat pengaplikasian Khiyar untuk pedagang

a) Membuat kenyamanan dan akan muncul kepuasan dari pedagang. Karena jika sudah mengaplikasikan Khiyar secara tidak langsung dari pihak pedagang sudah merasa diuntungkan, karena sudah saling terbuka dan sesuai kaidah syariat Islam. Ketika pembeli merasa puas secara langsung akan kembali lagi ke toko tersebut.

b) Dengan adanya Khiyar, maka penipuan dalam transaksi akan juga terhindarkan, karena adanya kejelasan dan hak yang sudah jelas. Karena transaksi dan akad dilakukan saat sebelum jual beli dilakukan jadi semua sudah jelas dan terbuka, sehingga pedagang juga tidak akan menerima komplain dari pembeli.

c) Pembeli dapat secara jujur dan transparan melakukan proses transaksi. Karena dengan adanya keterbukaan antara penjual, pembeli, dan barang yang dijual membuat perniagaan menjadi aman dan terjamin. Sehingga memudahkan untuk bertransaksi secara berkala dalam jangka waktu yang lama.

d) Memberikan kemudahan kepada pemilik harta dan menutup kesempatan orang yang rakus, sehingga tidak bisa berbuat sesuka hatinya. Yaitu dengan memberi kesempatan untuk melihat dan memeriksa barang, serta menimbang-nimbang kesesuaian harga dengan barangnya, agar para pelaku transaksi benar-benar tahu dengan jelas, sehingga tidak menyesal setelah melakukan transaksi tersebut.

e) Memberikan kesempatan kepada pelaku transaksi untuk membatalkan transaksi apabila terjadi kesalahan atau karena pihak penjual tidak bersedia memperbaiki cacat pada barangnya. Dan memudahkan pembeli untuk leluasa memilih barang yang disukai.

(2) Manfaat pengaplikasian Khiyar untuk pembeli

a) Pembeli merasa puas dan merasa diistimewakan karena pedagang menjamin barang yang dijual dengan transparan dan dengan kualitas yang sangat baik, sehingga memungkinkan pembeli untuk kembali membeli barang di toko tersebut.

b) Pembeli bisa membeli barang yang diinginkan sesuai dengan kebutuhan dan tidak perlu khawatir dengan harga jika membeli dengan jumlah yang pembelian yang cukup banyak karena harga sudah disepakati di awal.

c) Pembeli juga terhindarkan dari transaksi yang bersifat penipuan atau barang tidak sesuai, karena produk yang akan ditawarkan kepada pembeli sudah memenuhi syarat untuk dikonsumsi. Jadi pembeli mendapat kesempatan untuk memilih barang yang akan dibeli sebelum membayar.

d) Ketika barang yang sudah dibeli tidak sesuai dengan keinginan pembeli, pembeli juga berkesempatan untuk menukar atau mengembalikan sesuai dengan kesepakatan di awal. Karena pedagang sangat menjamin kepuasan pembeli dalam bertransaksi dengan metode Khiyar.

\section{KESIMPULAN}

Proses Khiyar yang terjadi pada pedagang sembako secara grosir di pasar Wage Kabupaten Nganjuk sudah diaplikasikan oleh beberapa pedagang. Berdasarkan hasil penelitian yang telah peneliti lakukan pada kegiatan transaksi jual beli sembako secara grosir di ketahui bahwa dalam akad mengenai sistem pengembalian sembako yaitu pengembalian harus didasarkan atas perjanjian lisan. Jika ditemukan sembako aib maka solusi sudah disiapkan oleh pihak penjual yaitu penjual telah 
menentukan solusi sejak awal jika terdapat pengembalian sembako tanpa adanya kesepakatan antara penjual dan pembeli. hal ini tidak sesuai dengan salah satu syarat.

Dengan adanya Khiyar, maka penipuan dalam transaksi akan juga terhindarkan, karena adanya kejelasan dan hak yang sudah jelas. Karena transaksi dan akad dilakukan saat sebelum jual beli dilakukan jadi semua sudah jelas dan terbuka, sehingga pedagang juga tidak akan menerima komplain dari pembeli

\section{UCAPAN TERIMA KASIH}

Untuk dapat menyelesaikan penelitian ini, penulis mendapatkan berbagai bantuan dari beberapa pihak. Oleh karena itu penulis berkewajiban menyampaikan rasa terima kasih sedalam-dalamnya, terutama kepada: Rektor Institut Agama Islam Pangeran Diponegoro (IAI PD) Nganjuk yang telah memberikan izin kepada penulis untuk dapat menyelesaikan studi akhir. Dekan Fakultas Syariah dan Ekonomi Islam, yang telah memberikan izin dan pengarahan pada peneliti.

\section{DAFTAR RUJUKAN}

Anis fuad \& Kandung Sapto Nugroho, panduaan Praktis Penelitian Kualitatif, Yogyakarta: Graha ilmu, 2014.

Anwal, Pengertian Ekonomi. Katagori Belajar Bisnis Pada 24 Mei 2020.

Ihyaul Ulum, Akuntansi Sektor Publik. 2004 (Malang, UMM Press) .

Mardani. Fiqh Ekonomi Syariah: Fiqh Muamalah, Bandung: Gaya Media Pratama. 2012.

Masruru, Nanang Taufik. "Pandangan Hukum Islam Terhadap Pelaksanaan Khiyar". Jakarta: Kencana, 2014.

Mustaq Ahmad, Etika Bisnis dalam Islam. (Jakarta: Pustaka Alkautsar2014) . 